\title{
Substitutability and disgorgement damages in contract
}

\author{
KATY BARNETT*
}

The principles governing the award of disgorgement damages for breach of contract remain opaque. In the leading judgment in Attorney-General $v$ Blake, ${ }^{1}$ Lord Nicholls proposed a 'legitimate interest' test for determining when a breach of contract would give rise to an account of profits. However, continuing uncertainty about what constitutes a legitimate interest has made the test notoriously difficult to apply. In that context, Lord Steyn's remark, that '[e]xceptions to the general principle that there is no remedy for disgorgement of profits against a contract breaker are best hammered out on the anvil of concrete cases', ${ }^{2}$ simply highlights the need for concrete criteria to guide the enquiry. The fact remains that, nine years after Blake was decided, and notwithstanding numerous cases addressing the question, there is no settled judicial approach as to when disgorgement of profits will be awarded for breach of contract.

This chapter suggests that the concept of 'substitutability' is an important key to the enquiry which must be made by courts. Substitutability is already a criterion for the award of specific relief. But the way in which substitutability is applied to determine a plaintiff's right to disgorgement in different contexts needs to be nuanced. This chapter explains that, for what are here called the 'second sale' cases, the central question is whether the subject matter of the contract was substitutable. However, the chapter goes on to explain that for the so-called 'agency problem' cases, substitutability is not the only factor, although it remains relevant. The plaintiff

\footnotetext{
- This paper is dedicated to my friend, teacher, mentor and thesis supervisor, Michael Bryan, without whose support I would not have undertaken postgraduate studies. Special thanks to Robert Chambers, Michael Bryan, Andrew Robertson, James Edelman and the editors for their comments on earlier drafts of this paper. Any errors, of course, remain ny own.

1 [2001] 1 AC 268 ('Blake'). 2 Ibid 291.
} 
must also have reposed trust in the defendant, or there must be another public policy reason for the contract to be effected by an award of disgorgement damages. These criteria suggest an important overlap between the award of disgorgement damages for breach of negative contractual covenants and account of profits for breach of fiduciary duty.

\section{A. Substitutability: a key to determining liability for disgorgement damages}

Substitutability is central to the justification of specific performance of contracts. Specific relief will be ordered in circumstances where the plaintiff would be unable (or would find it very difficult) to procure a substitute performance. ${ }^{3}$ Because the plaintiff will suffer a non-compensable loss as a result of the defendant's non-performance, the plaintiff is justified in compelling the defendant to perform the contract.

Various commentators have noted that if specific relief was or ought to have been available to a plaintiff in a contract claim, but is no longer available, it is likely that the plaintiff may be able to seek disgorgement damages. ${ }^{4}$ Disgorgement is awarded in lieu of performance if the promisee would have been or was awarded specific relief before the promisor put the remedy out of the promisee's reach. ${ }^{5} \mathrm{~A}$ similar analysis by Robert Stevens argues that damages are awarded as a substitute for a right of which a person has been deprived. ${ }^{6}$ Where the promisor has deprived the promisee of performance and made a profit thereby, it is argued that the 'next best' solution is to cause the defendant to disgorge his gains.

\footnotetext{
${ }^{3}$ Adderley v Dixon (1824) I Sim \& St 607, 610; 57 ER 239, 240 ('Adderley').

4 SM Waddams, 'Restitution as Part of Contract Law' in A Burrows (ed), Essays on the Law of Restitution (Clarendon Press, Oxford 1991) 197;JEdelman, Gain-Based Damages:Contract, Tort, Equity and Intellectual Property (Hart Publishing, Oxford 2002) 152-5; P Benson, 'Disgorgement for Breach of Contract and Corrective Justice: An Analysis in Outline' in JW Neyers, M McInnes and SGA Pitel (eds), Understanding Unjust Enrichment (Hart Publishing, Oxford 2004) 327-30; P Jaffey, 'Disgorgement and "Licence Fee Damages" in Contract' (2004) 20 JCL 1, 10; MA Eisenberg, 'The Disgorgement Interest in Contract Law' (2006) 105 Mich L Rev 559, 582; R Cunnington, 'The Measure and Availability of Gain-Based Damages for Breach of Contract' in R Cunnington and D Saidov (eds), Contract Damages: Domestic and International Perspectives(Hart Publishing, Oxford 2008) 205-42; R Cunnington, "The Inadequacy of Damages as a Remedy for Breach of Contract' in CEF Rickett (ed), Justifying Private Law Remedies (Hart Publishing, Oxford 2008) 115-45.

${ }^{5}$ Eisenberg (n 4) 584.

6 R Stevens, Torts and Rights (Oxford University Press, Oxford 2007) 60.
} 
These analyses all accept that disgorgement damages should only be ordered when: (1) damages are inadequate to compensate for breach; (2) specific relief is no longer available; and (3) the defendant has made a profit from breaching the contract. Disgorgement damages are a tertiary remedy, only available when the secondary remedy of specific relief is unavailable. It is also widely accepted that disgorgement damages should be available where the contractual relationship involves a concurrent fiduciary relationship. ${ }^{7}$

The principle of substitutability plays a key role in determining when damages are inadequate such that specific relief could, in principle, be available, and hence disgorgement damages in cases where specific relief is not, in fact, available. However, although substitutability helps establish whether disgorgement damages should be available for breach of contract, the thesis of this chapter is that it needs to be nuanced and its role further clarified. To this end, the case law can be broken down into two categories of cases where disgorgement damages may be available.

(1) 'Second sale' cases. Alice contracts with Boris, but Boris breaches his contract with Alice and sells to Conrad for a profit. Typically, the contract between Alice and Boris is no longer specifically enforceable but there is a profit for Boris to disgorge.

(2) 'Agency problem' cases ${ }^{8}$ Boris promises Alice he will not do a specific thing which relates to Alice's best interests, but Boris then breaches the contract and goes ahead and does the very thing which he has contracted not to do, making a profit as a consequence.

The chapter argues that, in both scenarios, some kind of advertent conduct is necessary in the context of breach of contract. This is because of the punitive and deterrent rationales behind disgorgement damages. There must be a conscious or advertent indifference to the rights of the plaintiff for the punishment to be deserved. ${ }^{9}$ Further, the deterrence aspect seems more appropriate and proportionate if the wrongful actions are conscious and advertent.

Substitutability is important in this context in establishing the blameworthiness of a defendant's conduct, as it helps to ascertain when it is

7 Edelman (n 4) 152-5.

8 'Agency' in this article is used in an economic sense rather than the legal sense. This will be discussed in further detail in Part C.

9 B Chapman and M Trebilcock, 'Punitive Damages: Divergence in Search of a Rationale' (1989) 40 Ala L Rev 741, 780-3. Cf JH Dawson, 'Restitution Without Enrichment' (1981) 61 B U L Rev 563, 614. 


\title{
Substitutability and disgorgement damages in contract
}

\author{
KATY BARNETT*
}

The principles governing the award of disgorgement damages for breach of contract remain opaque. In the leading judgment in Attorney-General $v$ Blake, ${ }^{1}$ Lord Nicholls proposed a 'legitimate interest' test for determining when a breach of contract would give rise to an account of profits. However, continuing uncertainty about what constitutes a legitimate interest has made the test notoriously difficult to apply. In that context, Lord Steyn's remark, that '[e]xceptions to the general principle that there is no remedy for disgorgement of profits against a contract breaker are best hammered out on the anvil of concrete cases', ${ }^{2}$ simply highlights the need for concrete criteria to guide the enquiry. The fact remains that, nine years after Blake was decided, and notwithstanding numerous cases addressing the question, there is no settled judicial approach as to when disgorgement of profits will be awarded for breach of contract.

This chapter suggests that the concept of 'substitutability' is an important key to the enquiry which must be made by courts. Substitutability is already a criterion for the award of specific relief. But the way in which substitutability is applied to determine a plaintiff's right to disgorgement in different contexts needs to be nuanced. This chapter explains that, for what are here called the 'second sale' cases, the central question is whether the subject matter of the contract was substitutable. However, the chapter goes on to explain that for the so-called 'agency problem' cases, substitutability is not the only factor, although it remains relevant. The plaintiff

\footnotetext{
- This paper is dedicated to my friend, teacher, mentor and thesis supervisor, Michael Bryan, without whose support I would not have undertaken postgraduate studies. Special thanks to Robert Chambers, Michael Bryan, Andrew Robertson, James Edelman and the editors for their comments on earlier drafts of this paper. Any errors, of course, remain ny own.

1 [2001] 1 AC 268 ('Blake'). 2 Ibid 291.
} 


\section{Contracts for sale of land}

Land has been 'accorded a unique status as a symbol of the self and as a resource closely linked to personal freedom, rank and power'. ${ }^{15}$ It has a 'peculiar and special value', and therefore is intrinsically nonsubstitutable. Specific performance of contracts for sale of land will usu$\ldots$ ally be ordered. ${ }^{16}$ However, some doubt has been cast over the special status of land by a majority of the Canadian Supreme Court in Semelhago $v$ Paramadevan. ${ }^{17}$ Sopinka J, in delivering the majority judgment, said in obiterthat developments in modern real estate meant every piece of real estate was no longer unique. ${ }^{18}$ His Honour concluded:

Specific performance should, therefore, not be granted as a matter of course absent evidence that the property is unique to the extent that its substitute would not be readily available ${ }^{19}$

As Robert Chambers has argued, this misunderstands the reasoning behind specific performance, because the purchaser may be able to find property with very similar features, but will not be able to obtain exactly the same land from another vendor. ${ }^{20}$ Damages cannot be an adequate response where a plaintiff is unable to get a full substitute for the benefit for which she bargained. Semelhago $v$ Paramadevan is contradicted in Australia by Barwick CJ's dicta in Pianta $v$ National Finance \& Trustees Ltd. ${ }^{21}$

Lake $v$ Bayliss ${ }^{22}$ and Bunny Industries Ltd $v$ FSW Enterprises Pty $L t d^{23}$ suggest that courts have long been willing effectively to award

${ }^{15}$ Dagan (n 14) 138.

16 Adderley (n 3); Dougan $v$ Ley (1946) 71 CLR 142 ('Dougan v Ley'). Specific performance of a contract for sale of land is nevertheless subject to discretionary considerations: see eg, Patel v Ali [1984] I Ch 283 (hardship on the defendant);Summers $v$ Cocks (1927) 40 CLR 321 (lack of clean hands of the plaintiff).

17 [1996] 2 SCR 415, 136 DLR (4th) I ('Semelhago v Paramadevan'). Note that La Forest) dissented on that issue, saying (at 2): 'However, given the assumption under which the case was argued, I prefer not to deal with the circumstances giving rise to entitlement to specific performance or generally the interpretation that should be given to the legislation authorizing the award of damages in lieu of specific performance. In considering modification to existing law, both these interdependent factors may well require examination, and the arguments in this case were not made in those terms.'

18 Ibid $10 .{ }^{19}$ Ibid.

20 R Chambers, 'The Importance of Specific Performance' in $S$ Degeling and ) Edelman (eds), Equity in Commercial Law (Lawbook Co, Sydney 2005) 431. Cf W Swadling, 'The Vendor-Purchaser Constructive Trust' in Degeling and Edelman (above) 463.

${ }^{21}$ (1964) 180 CLR 146, 151 (Barwick C)).

22 [1974] 1 WLR 1073 ('Lake v Bayliss') cited by Lord Nicholls in Blake (n l) 284.

${ }^{23}$ [1982] Qd R 712 ('Bunny Industries'). 
appropriate from a punitive and deterrent perspective to impose disgorgement damages. Justice Chapman and Michael Trebilcock have argued that, ordinarily, remedies which exact punishment and deterrence are not appropriate for breach of contract, even if the breach is intentional. ${ }^{10}$ The breaching party is not denying the relevance of the plaintiff's rights; rather he is prepared to pay damages flowing from that breach if proven. ${ }^{11}$

$\ldots$ However, the counter to this is that if a substitute performance cannot be procured, damages will be inadequate, and the defendant's conduct becomes a denial of the plaintiff's rights. If the subject matter of a contract is unique, the promisor's conduct is blameworthy because the promisee will be unable to procure a substitute performance from elsewhere. In such contracts, it is also appropriate that promisors should be deterred from breaching the contract and depriving the promisee of performance. On the other hand, if a performance is substitutable, then disgorgement damages should not be awarded, even if the breach is entirely advertent. ${ }^{12}$ In this sense, as will be discussed in the conclusion to the next section, substitutability leaves open the possibility of 'efficient breach'.

\section{B. Substitutability and second sale cases}

The second sale cases occur when a vendor sells property, goods or services to a purchaser, but then breaches his contract with the purchaser to sell the item more profitably to a third party. ${ }^{13}$ Whether or not disgorgement damages will be available depends on where the subject matter of the contract sits on the spectrum: from fungible property, goods or services at one end (which a plaintiff can easily procure from elsewhere) to unique property, goods or services at the other end (which cannot be procured from elsewhere). ${ }^{14}$ Looking at the categories of land, chattels and goods, shares and stock, and services in turn, the chapter will first consider the way in which courts have established whether or not the particular subject matter of a contract is substitutable for the purposes of awarding specific relief, and then whether or not courts have been prepared to order disgorgement damages.

${ }^{10}$ Chapman and Trebilcock (n 9). " $\quad$ Ibid 783. 12 Jaffey (n 4) 7-9.

13 The second sale cases encompass all kinds of benefits transferrable under contract, including land, goods, chattels and services.

${ }^{14} \mathrm{H}$ Dagan, 'Restitutionary Damages for Breach of Contract' (2000) I Theoretical Inquiries in Law 115, 134-36; S Thel and P Siegelman, 'The Role of Disgorgement in Contract Law' (Fordham Legal Studies Research Paper No 1353402 2009) $21<$ http://ssrn.com/ abstract $=1353402>$. 


\section{Contracts for sale of land}

Land has been 'accorded a unique status as a symbol of the self and as a resource closely linked to personal freedom, rank and power'. ${ }^{15}$ It has a 'peculiar and special value', and therefore is intrinsically nonsubstitutable. Specific performance of contracts for sale of land will usu$\ldots$ ally be ordered. ${ }^{16}$ However, some doubt has been cast over the special status of land by a majority of the Canadian Supreme Court in Semelhago $v$ Paramadevan. ${ }^{17}$ Sopinka J, in delivering the majority judgment, said in obiterthat developments in modern real estate meant every piece of real estate was no longer unique. ${ }^{18}$ His Honour concluded:

Specific performance should, therefore, not be granted as a matter of course absent evidence that the property is unique to the extent that its substitute would not be readily available ${ }^{19}$

As Robert Chambers has argued, this misunderstands the reasoning behind specific performance, because the purchaser may be able to find property with very similar features, but will not be able to obtain exactly the same land from another vendor. ${ }^{20}$ Damages cannot be an adequate response where a plaintiff is unable to get a full substitute for the benefit for which she bargained. Semelhago $v$ Paramadevan is contradicted in Australia by Barwick CJ's dicta in Pianta $v$ National Finance \& Trustees Ltd. ${ }^{21}$

Lake $v$ Bayliss ${ }^{22}$ and Bunny Industries Ltd $v$ FSW Enterprises Pty $L t d^{23}$ suggest that courts have long been willing effectively to award

${ }^{15}$ Dagan (n 14) 138.

16 Adderley (n 3); Dougan $v$ Ley (1946) 71 CLR 142 ('Dougan v Ley'). Specific performance of a contract for sale of land is nevertheless subject to discretionary considerations: see eg, Patel v Ali [1984] I Ch 283 (hardship on the defendant);Summers $v$ Cocks (1927) 40 CLR 321 (lack of clean hands of the plaintiff).

17 [1996] 2 SCR 415, 136 DLR (4th) I ('Semelhago v Paramadevan'). Note that La Forest) dissented on that issue, saying (at 2): 'However, given the assumption under which the case was argued, I prefer not to deal with the circumstances giving rise to entitlement to specific performance or generally the interpretation that should be given to the legislation authorizing the award of damages in lieu of specific performance. In considering modification to existing law, both these interdependent factors may well require examination, and the arguments in this case were not made in those terms.'

18 Ibid $10 .{ }^{19}$ Ibid.

20 R Chambers, 'The Importance of Specific Performance' in $S$ Degeling and ) Edelman (eds), Equity in Commercial Law (Lawbook Co, Sydney 2005) 431. Cf W Swadling, 'The Vendor-Purchaser Constructive Trust' in Degeling and Edelman (above) 463.

${ }^{21}$ (1964) 180 CLR 146, 151 (Barwick C)).

22 [1974] 1 WLR 1073 ('Lake v Bayliss') cited by Lord Nicholls in Blake (n l) 284.

${ }^{23}$ [1982] Qd R 712 ('Bunny Industries'). 
disgorgement damages for a breach of a contract to sell land, well before Blake This is unsurprising, given the intrinsically non-substitutable nature of land. In each case, the vendor breached the contract with the initial purchaser and sold the land for a profit to a third party. In Lake $v$ Bayliss, the matter was further complicated because the vendor contracted to convey the land to the purchaser in return for the purchaser withdraw- ing two legal claims against her. In both cases, the vendor was said to be a trustee of the proceeds of sale and had to account for them (subject to the purchaser providing the requisite consideration). ${ }^{24}$ The effect was to force the vendor to disgorge his or her profits to the purchaser.

The result in these cases has been justified by reference to the constructive trust which is said to arise upon execution of the contract of sale and before settlement occurs. But the trust analogy has always been unsatisfactory, as noted in Lysaght $v$ Edwards ${ }^{25}$ Sir Thomas Plumer MR in Wall $v$ Bright ${ }^{26}$ described the vendor as 'in progress towards' bare trusteeship. A vendor will only become a bare trustee when the whole of the purchase moneys are paid and the vendor is bound by contract to convey. In any case, the Australian High Court has thrown the constructive trust analysis into doubt in Tanwar Enterprises Pty Ltd $v$ Cauchi ${ }^{27}$ US courts have also rejected the constructive trust analysis. ${ }^{28}$

The constructive trust analysis suffers particular problems in the second sale cases, because it is said to arise from the specifically enforceable nature of the contract for sale of land. In Lake $v$ Bayliss and Bunny Industries, the contracts of sale were no longer actually specifically enforceable, because the land had been conveyed to a third party. Nonetheless, in both cases, the courts found that the vendor was subject to fiduciary duties arising from the constructive trust.

In an attempt to bypass the difficulties of the constructive trust analysis, American scholars have categorized the remedies in the second sale cases as expectation damages. ${ }^{29}$ There is said to be an implied term in contracts of sale that the vendor will not seek out or accept more profitable offers, and the buyer is said to pay an implicit premium for that promise. It is argued that when a vendor is forced to disgorge his profits in

24 Lake v Bayliss (n 22) 1076; Bunny Industries (n 23) 717-19.

25 (1876) 2 Ch D 499, 510. See also Holroyd v Marshall (1862) 10 HLC 191, 11 ER 999; Swadling (n 20).

${ }^{26}$ (1820) I Jac \&W 494, 503; 37 ER 456, $459 . \quad{ }^{27}$ (2001) 217 CLR 315 ('Tanwar').

${ }^{28}$ Laurin $v$ DeCarolis Construction Co, 363 NE 2d 675 (Mass 1977).

29 EA Farnsworth, 'Your Loss or My Gain? The Dilemma of the Disgorgement Principle in Breach of Contract' (1985) 94 Yale LJ 1339, 1364-5; Eisenberg (n 4) 582. 
a second sale scenario, this is a form of expectation damages, because the purchaser has paid for the right to any profit gained by the vendor pursuant to the implied term. ${ }^{30}$ The difficulty with this analysis is that, like the constructive trust analysis, it involves a fiction: namely, that if the vendor sold to someone else, the parties agreed the purchaser would be entitled to the profit made by the vendor. This chapter suggests that it is better to $\therefore$ avoid such fictions altogether.

In Blake, Lord Nicholls suggested that Lake $v$ Bayliss should be seen as a case of disgorgement of profits for breach of contract. ${ }^{31}$ The second sale cases make much more sense if one sees them in this light, and the constructive trust analysis is abandoned once the land has been conveyed to a third party. Further, this avoids unduly stretching the definition of expectation damages by importing fictions about implied clauses.

\section{Contracts for sale of goods or chattels}

Where contracts for sale of goods or chattels involve a good or chattel that can easily be obtained elsewhere, the general principle is that damages will be adequate compensation for non-performance. ${ }^{32}$ However, a good or chattel may be non-substitutable if it is rare, ${ }^{33}$ or it would be very difficult for a plaintiff to procure an equivalent substitute performance because the defendant is particularly well situated to meet the plaintiff's needs. ${ }^{34}$ Sometimes, there may be an instalment contract to supply goods and services over a long period of time. ${ }^{35}$ This is not substitutable because a complex contract cannot be replaced with an identical deal. In some circumstances, although a good or chattel is generally fungible, it

${ }^{30}$ Eisenberg (n 4) 582. ${ }^{31}$ Blake (n 1$) 284$.

32 Adderley (n 3) 610;240. However, Thel and Siegelman (n 14) 9-15 argue that even where compensatory damages are concerned, the market damage measure means disgorgement is effectively available if the market value is greater than the original contract value - see eg, Goods Act 1958 (Vic) s 56(3) for an Australian example.

${ }^{33}$ Falcke v Gray (1859) 4 Drew 651, 62 ER 250; Burr v Bloomburg, 101 NJ Eq 615, 318 A 876 (1927); Dougan v Ley (n 16); Aristoc Industries Pty Ltd v R A Wenham (Builders) Pty Ltd [1965] NSWR 581.

${ }^{34}$ See eg, North $v$ Great Northern Railway Company (1860) 2 Giff 64, 66 ER28; Sky Petroleum Ltd v VIP Petroleum Ltd [1974] I WLR 577 ('Sky Petroleum').

${ }^{35}$ Buxton y Lister (1746) 3 Atk 383, 26 ER 1020; Adderley (n 3); Eastern Rolling Mill $v$ Michlovitz, 157 Md 51, 145 A 378 (1929); Sky Petroleum (n 34); Thomas Borthwick v South Otago Freezing [1978] 1 NZLR 538. Cf Fothergill v Rowland (1873) LR 17 Eq 132, 140; Laclede Gas Co $v$ Amoco Oil Ca 845 F 2d 76, 80 (4th Cir, 1975). 
may be unavailable because of particular circumstances at that time. ${ }^{36}$ For example, in Howard Perry \& Co $v$ British Railways, ${ }^{37}$ members of the National Union of Railwaymen had refused to transport steel in a gesture of solidarity with striking steelworkers. The plaintiffs were steel stockholders, and had consignments of steel waiting to be delivered in two of the defendant's depots. The steel could not be kept for a long period of - time because it would harden and become unmalleable, and would thus be unworkable. The defendants would not allow the plaintiffs to collect the steel from the depots themselves. Accordingly, the plaintiffs sought delivery up of the goods pursuant to the contract. Megarry VC explained why steel was non-substitutable in the particular circumstances:

If a plaintiff can easily replace the goods detained by purchasing their equivalent on the market, then the payment of damages out of which the price of the equivalent may be paid is adequate compensation to the wronged plaintiff, and there is little or no point in making an order for the delivery of the goods. Far better to let the plaintiff fend for himself with the defendant's money.

In normal times, the steel here in dispute might indeed be in this category; but these times are not normal, and at present steel is obtainable on the market only with great difficulty, if at all. If the equivalent of what is detained is unobtainable, how can it be said that damages are an adequate remedy? They plainly are not. Mr Irvine observed that at present 'steel is gold', and one can see what he meant. Yet even that may not do justice to his cause, since as far as I know gold is still available on the open market to those who pay the price. ${ }^{38}$

Disgorgement damages have been awarded in Adras Building Material Ltd $v$ Harlow \& Jones $\mathrm{GmbH},{ }^{39}$ an Israeli case which is highly reminiscent of Howard Perry. The defendant Harlow, a German company, entered into a contract of sale with the plaintiff Adras, an Israeli company. The contract provided that the defendant would supply the plaintiff with 7,000 tons of iron at a price of 570 Deutschmarks per ton. There was a delay in delivery because of the Yom Kippur War in October 1973, but 5,025 tons were shipped to the plaintiff in early 1974 . On 8 April 1974, the defendant told the plaintiff that it had to sell the remaining iron because

${ }^{36}$ Curtice Bros $v$ Catts, 72 NJ Eq 831, 833; 66 A 935, 936 (1907) (scarcity of tomatoes for a cannery); Sky Petroleum (n 34) (scarcity of petroleum); Eastern Air Lines $v$ Gulf Oil Corporation, 415 F Supp 429, 442-3 (1975); Howard Perry \& Co v British Railways [1980] 1 WLR 1375 ('Howard Perry').

37 Howard Perry (n 36). ${ }^{38}$ Ibid 1383 (emphasis added).

${ }^{39}$ (1998) 42(1) PD 221 ('Adras') translated in (1995) 3 RLR 235, 271. 
of high storage costs. In fact the price of iron had spiked, and the defendant profited by selling the iron to a third party in Hamburg for a price of DM804.70 per ton. The plaintiff did not obtain an alternative supply of iron and sued to recover damages for breach of contract pursuant to the Sale (International Sale of Goods) Law 1971 (Israel), ${ }^{40}$ and to recover the profit made by the defendant in respect of the sale of the remaining iron. ${ }^{41}$

A majority of the Supreme Court of Israel ${ }^{42}$ found that the plaintiff was entitled to recover the defendant's profit. Barak J noted that the plaintiff had a right under Israeli law to specific performance, and suggested that disgorgement was appropriate because the defendant had deprived the plaintiff of its right to performance. ${ }^{43}$ It has been suggested that Adras represents a dangerously broad approach to disgorgement da mages. ${ }^{44}$ The Court did not consider whether Adras could have procured a substitute performance. However, if the Court had found that the Yom Kippur War had prevented Adras from procuring a substitute performance, then the result would have been justifiable. Substitutability would have provided a coherent limitation on the Adras principle.

If it is difficult to procure a substitute performance, and specific relief is no longer available, then disgorgement damages should also be available. For example in Dougan $v$ Ley, the contract involved the transfer of a taxi licence which was scarce and difficult to acquire, but not impossible ${ }^{45}$ The plaintiff sought specific performance and succeeded in gaining it, so clearly the court regarded the benefit under the contract as non-substitutable. If for some reason specific performance was no longer available, but there was a profit from the on-sale of the taxi licence to a third party, then, in the absence of relevant defences, disgorgement damages should have been available.

${ }^{40}$ Authorized English translation; Israeli Ministry of Justice, Laws of the State of Israel (Vol 25) 32. This statute implements the Convention Relating to a Uniform Law on the International Sale of Goods (opened for signature 1 July 1964, entered into force 18 August 1972) 834 UNTS 107 into Israeli law.

41 In a previous hearing, the Supreme Court had held that the plaintiff had never terminated the contract, and therefore the plaintiff had failed to prove any loss: see Adras Building Material Ltd v Harlow \& Jones GmbH (1983) 37(4) PD 225.

42 Comprised of S Levin; Barak and Bach JJ. Ben Porath VP and D Levin J dissented on the basis that the property in question was non-specific.

${ }^{43}$ Adras (RLR) (n 39) 271 citing Rabihai v Man Shaket Ltd (in liq) (1977) 33(2) PD 281, 295. See also Contract (Remedies) Law 1970 (Israel) s 3.

${ }^{44}$ H Dagan, 'The Distributive Foundation of Corrective Justice' (1999) 98 Mich L Rev 138.

${ }^{45}$ Dougan v Ley (n 16) 151-2 (Dixon )), 153-4 (Willians I). 


\section{Contracts for shares and stock}

Generally, shares are substitutable, and will be readily available on the open market at a certain price. Public shares on the open market are likely to be substitutable, and if they are, a court will not order specific performance for a contract for the sale of shares or stock. ${ }^{46}$ However, sometimes there will not be an adequate market for a particular share or stock. ${ }^{47}$ In other circumstances, the market price for shares might be uncertain or there may be a risk that requiring the plaintiff to purchase the shares with damages will prejudice the plaintiff or a third party. In these circumstances, a court will also order specific performance. ${ }^{48}$

If a second sale case arose which involved unique shares or a situation where the market price was uncertain, it is suggested that by analogy with the cases above, disgorgement damages should be available.

\section{Contracts for services}

The question of the substitutability of personal services is fraught with difficulty. Courts are generally reluctant to order specific performance for contracts for services ${ }^{49}$ on the basis that it is inappropriate to compel an unwilling defendant to maintain a continuous personal relationship with the plaintiff..$^{50}$

${ }^{46}$ Hyer $v$ Richmond Traction Co, 168 US 471, 483 (1897); Re Schwabacher, 98 LT 127, 128 (1907) ('Schwabacher'); Chinn v Hochstrasser [1979] Ch 447, 470.

47 Cudv Rutter (1719) 1 P Wms 569, 24 ER 521; Duncuft $v$ Albrecht (1841) 12 Sim 189, 59 ER 1104; Paine v Hutchinson (1868) LR 3 Ch 388; Dougan v Ley (n 16) 151; General Securities Corporation $v$ Welton, 223 Ala 299, 135 So 329 (1931) ('General Securities'); Rudder $v$ George Hudson Holdings Ltd [1972] 1 NSWLR 529; Georges $v$ Wieland [2009] NSWSC 733 ('Georges $v$ Wieland') [17]-[25].

48 Schwabacher (n 46) 128; General Securities (n 47); ANZ Executors and Trustees Ltd $v$ Humes Ltd [1990] VR 615, 630-1 (Brooking J); Georges $v$ Wieland (n 47).

49 Rigby v Connol (1880) 14 Ch D 482, 487 (Jessel MR) ('Rigby'); H W Gossard Co v Crosby, 132 Iowa 155, 170, $109 \mathrm{NW} 483,488-9$ (1906) ('HW Gossard Co'); J C Williamson Ltd v Lukey and Mulholland (1931) 45 CLR 282 ('J C Williamson') 293 (Starke J); Hogan v Tumut Shire Council (1954) 54 SR (NSW) 284 ('Hogan'); Francis v Municipal Councillors of Kuala Lumpur [1962] 3 All ER 633 ('Francis'); Sampson v Murray, 415 US 61, 83 (1974) ('Sampson v Murray'); American Law Institute, Restatement (Second) of the Law of Contracts (American Law Institute Publishers, St Paul 1981) $\$ 367$. The US position is further complicated by the Thirteenth Amendment to the Constitution, which says 'neither slavery nor involuntary servitude' shall exist in the US.

so Wolverhampton and Walsall Railway Co v London NWRwy Co (1873) LR 16 Eq 433; Rigby (n 49) 487 (Jessel MR); HW Gossard Co (n 49) 170; 488-9; J C Williamson (n 49) 293 
However, in some circumstances, a court may order an injunction to restrain a breach of a negative covenant where a defendant has agreed not to provide their services to any person other than the plaintiff, particularly where the services involved are unique. The cases involve employees such as opera singers, ${ }^{51}$ acrobats, ${ }^{52}$ sportsmen, ${ }^{53}$ actors and actresses ${ }^{54}$ and television presenters, ${ }^{55}$ all of whom provide unique services. In US cases, there is explicit consideration of the uniqueness of the services provided ${ }^{56}$ because of the way in which Lumley $v$ Wagner ${ }^{57}$ was interpreted by US textbook writers. ${ }^{58}$ Courts effectively consider substitutability as a determinant of injunctive relief. If an employee can easily be replaced, damages will suffice, but if an employee possesses special qualities and has agreed not to move to a competitor, they will be restrained by injunction (so long as such restraint is reasonable).

Sometimes it is difficult to predict when the services of an employee will be unique. In two American cases decided within days of one another,

(Starke J); Atlas Steels (Australia) Pty Ltd v Atlas Steels Ltd (1948) 49 SR (NSW) 157 ('Atlas Steels') 161 (Sugarman J); Hogan (n 49); Francis (n 49); Sampson v Murray (n 49) 83.

${ }^{51}$ Lumleyv Wagner (1852) 1 De GM \& G 604, 42 ER 687 ('Lumley v Wagner'); Duff v Russell, 14 NYS 134, 60 J \& S 80 (1891); Oscar Hammerstein v Marguerite Mann, 122 NYS 276 (1910); Chapin v Powers, 73 NYS (2d) 854 (1947).

52 John Cort v Lassard \& Lucifer, 18 Ore 221, 22 P 1054 (1889) (non-unique acrobats); Keith v Kellermann, 169 F 196 (1909) (unique diver); Shubert Theatrical Cov Rath, 271 F 827, 20 ALR 846 (1921) (unique acrobats).

53 Philadelphia Ball Club Ltd v Lajoie, 202 Pa 210,51 A 973 (1902) ('Philadelphia Ball Club'); American Baseball and Athletic Association v Harper 54 Cent L J 449 (1902) ('American Baseball') (baseballers); Hawthorn Football Club Ltd v Harding [1988] VR 49 ('Harding'); Buckenara $v$ Hawthorn Football Club Ltd [1988] VR 39 (Buckenara') (AFL footballers); Bulldogs Rugby League Club v Williams [2008] NSWSC 822 ('Williams') (ARL footballers).

${ }^{54}$ Montague v Flockton (1873) $16 \mathrm{LR}$ Eq 189; Daly v Smith (1874) 49 How Pr 150; Carter v Ferguson, 12 NYS 580, 58 Hun 569 (1890); Grimston v Cuningham (1893) 1 QB 125 ('Grimston'); Warner Brothers Pictures Inc v Nelson [1937] I KB 209 ('Nelson'); Marco Productions Ltd v Pagola [1945] $1 \mathrm{~KB} 111$ ('Marco Productions'); Warner Brothers Pictures Inc $v$ Ingolia [1966] NSWR 988 ('Ingolia').

${ }_{55}$ Evening News Association v Peterson, 477 F Supp 77 (1979); American Broadcasting Company v Wolf, 52 NY (2d) 394, 420 NE (2d) 363, 438 NYS (2d) 482 (1981); Currov Beyond Productions Pty Ltd (1993) 30 NSWLR 337 ('Curro').

${ }^{56}$ See eg, Bethlehem Engineering Export Co v Christie, 105 F (2d) 933, 935 (1939) (Learned Hand J).

57 Lumleyv Wagner (n 51).

${ }^{58}$ JN Pomeroy, A Treatise on Equity Jurisprudence (Vol 4) (4th edn Bancroft-Whitney Company, San Francisco 1919) \$1343, 3218-16. First edition cited with approval in Philadelphia Ball Club (n 53) 216; 973. See also JN Pomeroy, Treatise on the Specific Performance of Contracts (3rd edn Banks \& Company, Albany 1926) \$24, 75-7. Earlier edition also cited with approval in Philadelphia Ball Club (n 53) 216; 973. 
both of which involved professional baseball players, ${ }^{59}$ the result reached by the respective courts were diametrically opposed, so that it has been said:

The one has a solemn judicial finding that he is a person of such attainments in his profession that his position cannot possibly be filled. The other is decreed to be simply an ordinary person, whose place can easily be filled, and whose absence from his post can result in no particular or irreparable injury. Lajoie's professional reputation is established and enhanced at the cost of his freedom, while Harper gets his freedom at the expense of his professional reputation..$^{60}$

It seems that in the US, courts are more likely to restrain employees with a unique public persona than they are to restrain salespersons and managers. ${ }^{61}$

By contrast, Australian and English courts do not explicitly consider the unique nature of the service provided, ${ }^{62}$ although some Australian cases say that the principle in Lumley $v$ Wagner applies to contracts for 'special services', inferring that the court is cognizant of the quality of the services involved. ${ }^{63}$ Nevertheless, analysis of the case law suggests that substitutability still underlies the reasoning of courts. Actors, footballers, newsreaders and the like will be restrained from breaching a promise not to work for a competitor, so long as the restraint is reasonable and not too long in duration. ${ }^{64}$ Managers, ${ }^{65}$ travelling salespersons, ${ }^{66}$ porters ${ }^{67}$ or other ordinary employees ${ }^{68}$ are far less likely to be restrained from working for a competitor. There are instances where courts will restrain an ordinary employee from working for a competitor for a

59 Philadelphia Ball Club (n 53) (injunction granted); American Baseball (n 53) (injunction refused).

${ }^{60}$ Note to Philadelphia Ball Club Ltd v Lajoie, 90 American State Rep 627, 649 (1902).

${ }^{61}$ HW Gossard Co (n 49); Clark Paper er Manufacturing Co $v$ Stenacher, 236 NY 312, 140 NE 708 (1923).

62 The exception to this is Kekewich J's decision at first instance in Whitwood Chemical Company $v$ Hardman ('Whitwood') reproduced at [1891] 2 Ch 416, 419-23.

${ }^{63}$ Atlas Steels (n 50) 164, 165; Curro (n 55) 347; Williams (n 53) [53]-[54].

64 Grimston (n 54); Nelson (n 54); Marco Productions (n 54); Ingolia (n 54); Harding (n 53); Buckenara(n 53); Curro (n 55); Williams (n 53).

65 Whitwood (n 62); Davis v Foreman [1894] 3 Ch 654; Mortimer v Beckett (1920) I Ch 571; Page One Records v Britton [1968] I WLR 157 (Page One Records'); Warren v Mendy [1989] I WLR 853 ('Warren $v$ Mendy').

${ }^{66}$ Ehrman v Bartholomew [1898] 1 Ch 671 ('Ehrman').

67 Ryan v Mutual Tontine Westminster Chambers Association [1893] I Ch 116.

${ }^{68}$ Rely-A-Bell Burglar and Fire Alarm Company Ltd v Eisler [1926] I Ch 609 ('Rely-A-Bell'); Heine Bros (Aust) Pty Ltd v Forrest [1963] VR 383 (Heine Bros'). 
limited time, so long as the restriction does not restrain the employee from any employment. ${ }^{69}$

Clearly substitutability is not the only issue at play in these cases. First, courts do not wish to force people to work in jobs where they are unhappy or if they could get a better opportunity elsewhere. Second, using the facts of Curro $v$ Beyond Productions Pty $L t d^{70}$ as an illustration, if a newsreader is prevented from working for another company, there is still a vast range of ordinary professions in which she can work. However, if Ms Curro had been a woman with limited skills, she would have found it far more difficult if the court had restrained her from working as a waitress, making her effectively unemployable. It follows that if a restriction contained in a covenant is excessively severe, courts will refuse to enforce it or limit its operation. ${ }^{71}$ Similarly, if relations between the parties have broken down and it is simply not feasible to require co-operation, ${ }^{72}$ courts will also refuse to award an injunction forcing the parties to work together. The common law doctrine of restraint of trade also informs the attitude of the courts. Under this doctrine, contractual obligations restricting someone's ability to trade are void by reason of illegality unless they are reasonable and in the interests of both contracting parties and of the public at large. ${ }^{73}$ Courts are particularly concerned to safeguard the right of individuals to work in their chosen trade or profession without unjust restriction, and thus they will scrutinize restraints on employment more closely. ${ }^{74}$

Generally, disgorgement damages have not been thought to be available for breach of a contract for services. ${ }^{75}$ However, Christopher Wonnell has argued that by removing remedies for employers, employees may be

69 William Robinson \& Co v Heuer [1898] 2 Ch 451 ('William Robinson'); Chapman v Westerby [1913] WN 277 ('Chapman').

${ }^{70}$ Curro (n 55).

${ }^{7}$ Ehrman (n 66); Heine Bros (n 68); William Robinson (n 69); Whitwood (n 62) and Chapman (n 69). Cf Rely-A-Bell (n 68).

72 Page One Records (n 65); Warren v Mendy (n 65).

${ }^{73}$ Bacchus Marsh Concentrated Milk Co Ltd v Joseph Nathan \& Co Ltd (in liq) (1919) 26 CLR 410; Esso Petroleum Co Ltd v Harper's Garage (Stourport) Ltd [1968] AC 269; Amoco Australia Pty Ltd v Rocca Bros Motor Engineering Co Pty Ltd [1975] AC 56].

74 See eg, Lindner v Murdock's Garage (1950) 83 CLR 628, 633; Butt v Long (1953) 88 CLR 476; Minnesota Mining o Manufacturing (Australia) Pty Ltd $v$ Richards[1963] NSWR 1613; Buckley v Tutty (1971) 125 CLR 353; Forbes v NSW Trotting Club Ltd (1979) 143 CLR 242; Geraghty v Minter(1979) 142 CLR 177; Hughes $v$ Western Australian Cricket Association (Inc) (1986) 69 CLR 660; Rentokil Pty Ltd v Lee (1995) 66 SASR 301. Cf Curro (n 55) 346.

75 James Edelman has suggested that disgorgement damages ought to have been available in Lumley $v$ Wagner (n 51 ) had Ms Wagner profited as a result of her breach: Edelman (n 4) 158. 
disempowered, and that the 'enforced servitude' objection specifically to performing contracts for services should be thoroughly questioned. ${ }^{76}$ He argues that disgorgement damages could be a way of solving the dilemma:

To isolate and safeguard only an employee's interest in controlling her human relationships, the law should refuse an injunction against any employee who is willing to disgorge any economic profit from her breach of contract. Courts could properly enjoin an employee who could not demonstrate improper conduct by her employer, and who would not disgorge the economic profit from her breach, from working for a competitor. ${ }^{77}$

Accordingly, it is arguable that disgorgement damages should be paid by breaching employees to enable them to leave the service of employers for whom they no longer wish to work. Disgorgement damages better balance the competing interests of the parties than an injunction: on the one hand, they recognize the plaintiff's interest in the defendant's unique performance, but on the other hand, they allow the defendant to get another job. ${ }^{78}$ In addition, the restraint of trade concerns which may arise when an injunction is awarded do not arise for disgorgement damages.

\section{Second sale cases and efficient breach}

It can be seen that substitutability helps to establish when disgorgement damages should be available for second sale cases, where a promisor breaches a contract to sell at a profit to a third party.

Substitutability also helps to clarify when a promisor should be allowed to 'efficiently breach' in a second sale scenario. Efficient breach theory argues that a promisor should be able to breach his contract and enter into a more profitable contract with a third party. ${ }^{79}$ This is said to maximize efficiency in the marketplace. Clearly courts are concerned with such issues - the common law restraint of trade doctrine, for example, seeks to

76 CT Wonnell, 'The Contractual Disempowerment of Employees' (1993) 46 Stan L Rev 87.

77 Ibid 136 (emphasis added).

${ }^{78}$ Note Williams (n 53), where an Australian Rugby League player, Sonny Bill Williams, sought to play for a French Rugby Union club, Toulon, in breach of his five-year contract to play with the Bulldogs Rugby League Club Ltd. The Bulldogs were successful in obtaining an injunction to restrain Williams from playing for Toulon, but released Williams after Toulon paid a 'transfer fee' of $€ 300,000$-effectively a partial disgorgement of profits by agreement. See <http://www.telegraph.co.uk/sport/rugbyunion/club/2580942/Sonny. Bill-Williams-set-to-make-Toulon-debut-against-Saracens - Rugby-Union.htmls.

79 See eg, R Posner, Economic Analysis of Law (5th edn Aspen Law \& Business, New York 1998) 131-9. 
maximize efficiency and competition in the marketplace. Equally clearly, if one accepts efficient breach without qualification, it is prima facie problematic for the second sale cases, which involve precisely this scenario. Disgorgement damages for breach of contract have been criticized by supporters of efficient breach because they are said to remove the incentive for the promisor to breach his contract and enter into a more efficient contract, ${ }^{80}$ so that the only way the promisor can extricate himself from the contract is to negotiate a release from the contract. This is said to create a 'bilateral monopoly' where the cost of negotiation between promisor and promisee is prohibitively high. ${ }^{81}$

First, it is important to note that the assumptions which underlie efficient breach have been questioned in certain important respects which will not be canvassed in detail here. ${ }^{82}$ However, even if one accepts the fundamental premise, there will only be a bilateral monopoly where the subject matter of the contract is not available on the market. ${ }^{83}$

Let us say, for example, Alice has made a contract with Boris which says that Boris will supply her with 2,000 widgets. If widgets are incredibly rare, and Boris is the only supplier in the world market, Alice will not be able to procure a substitute performance. This means that there will be a bilateral monopoly if Boris wants to negotiate with Alice to get out of the contract, but in any case, it is likely that a court would not let Boris get out of the contract. Substitutability determines that this is a case for specific performance.

${ }^{80}$ See D Campbell, 'The Treatment of Teacher $v$ Calder in AGv Blake' (2002) 65 MLR 256; D Campbell and D Harris 'In Defence of Breach: A Critique of Restitution and the Performance Interest' (2002) 22 JLS 208; D Campbell, 'The Extinguishing of Contract (2004) 67 MLR 818. See also S de Long, 'The Efficiency of a Disgorgement as a Remedy for Breach of Contract' (1989) 22 Ind L Rev 737, who accepts efficient breach theory, but recognizes that disgorgement may be economically efficient in some circumstances. Posner himself is prepared to allow breach where it is 'opportunistic': Posner (n 79) 119.

91 See R O'Dair, 'Restitutionary Damages for Breach of Contract and the Theory of Efficient Breach: Some Reflections' (1993) 46 CLP 113, 131; LD Smith, 'Disgorgement of the Profits of Breach of Contract: Property, Contract and "Efficient Breach"' (1995) 24 CBLJ 121, 134-5; Thel and Siegelman (n 14) 20.

82 See IR Macneil, 'Efficient Breach of Contract: Circles in the Sky' (1982) 68 Va L Rev 947; D Friedmann, 'The Efficient Breach Fallacy' (1989) I8 JLS 1; Smith (n 81); P Jaffey, 'Efficiency, Disgorgement and Reliance in Contract: A Comment On Campbell and Harris' (2002) 22 LS 570; M Eisenberg, 'Actual and Virtual Specific Performance, the Theory of Efficient Breach, and the Indifference Principle in Contract Law' (2005) 93 California LR 975, 989-96; R Cunnington, 'Should Punitive Damages Be Part of the Judicial A rsenal in Contract Cases?' (2006) 26 LS 369, 384-9; Eisenberg (n 4) 571-2.

${ }^{83}$ Thel and Siegelman (n 14) 20. 
By contrast, if Boris wants to breach his contract with Alice, and she can easily procure the widgets from elsewhere, there will not be a bilateral monopoly, and Boris will be free to breach or to negotiate a release. Therefore, substitutability helps to provide a more nuanced version of efficient breach theory, having regard to the scarcity or otherwise of the subject matter of the contract.

2. This chapter now turns to the criteria for award of disgorgement damages for breach of negative covenant and breach of fiduciary duty in the so-called 'agency problem' cases. As will be seen, there is some overlap with the second sale cases, but the approach does need to be nuanced because of the particular policy considerations involved.

\section{Substitutability and the agency problem cases}

\section{The overlap of breach of fiduciary duty and injunctions to restrain breach of negative covenant}

The contractual rights granted by negative covenants ${ }^{84}$ and those entailed in cases which involve fiduciary duties could be said to be intrinsically non-substitutable because they are intangible benefits which cannot be bought or sold in any market. ${ }^{85}$ Thus, these cases are broadly akin to the second sale cases where the defendant has put specific performance out of the reach of the plaintiff. Substitutability also helps explain breach of negative covenant cases where disgorgement is awarded as a surrogate for expectation damages. ${ }^{86}$ Nonetheless, substitutability does not provide a complete explanation of the outcome of the negative covenant cases. If substitutability were the sole criterion, then every breach of negative covenant would give rise to disgorgement damages. However, this paper will suggest that something more is needed in the negative covenant cases. We need to compare breach of negative covenant cases with those cases involving concurrent breaches of fiduciary duty and contract in order to provide a more complete analysis.

There is a kinship between cases involving breaches of negative covenant and cases involving concurrent breaches of fiduciary duty and contract.

${ }^{84}$ It should be noted that the personal services cases are also negative covenant cases, but they will not be considered in this section as they fit better with the second sale cases. The negative covenant cases overlap with other areas, and thus have always been difficult to categorize.

${ }^{85}$ D Laycock, 'The Death of the Irreparable Injury Rule' (1990) 103 Harv L Rev 687, 707-8.

${ }^{86}$ Eisenberg (n 4) 587-8. 
This was adverted to by Lord Nicholls in Blake when he described George Blake's contractual obligations as 'closely akin to a fiduciary obligation'. ${ }^{87}$ Whether Boris is subject to a fiduciary duty or a negative covenant, he contracts with Alice not to do a specific thing which relates to Alice's best interests, but Boris then breaches the contract and goes ahead and does the very thing which he has contracted not to do, and profits thereby.

In the case of fiduciary duties Boris is obliged not to allow his personal interests to conflict with his duty to serve Alice's interests and not to make an unauthorized or secret profit. In the case of a negative covenant, Boris' obligation is not to do the particular thing specified in the negative covenant. In addition, however, it will be argued that where trust is conferred on Boris, he also has an obligation not to profit, and if he does profit, that profit should be stripped from him. The common factor between the breach of fiduciary duty cases and the negative covenant cases is the trust conferred on the promisor.

Both kinds of contract involve what Steve Thel and Peter Siegelman call 'the agency problem'. ${ }^{88}$ 'Agency' in this context refers not to the legal concept of agency, but the economic concept of principal-agent. This form of analysis attempts to ascertain how a principal can design a contract which motivates another individual, his agent, to act in the principal's interests. ${ }^{89}$ An agency problem arises when there is information asymmetry concerning what action the agent either has undertaken or should undertake. Agency problems can create a situation of 'moral hazard' because the party that is insulated from risk generally has more information about its actions and intentions than the party paying for the negative consequences of the risk. Part of the difficulty in both fiduciary duty cases and negative covenant cases is the difficulty the promisee has in monitoring the promisor's performance. The promisor can breach before the promisee has a chance to issue an injunction, and the breach cannot be undone. The promisor is not the one who suffers from the breach; indeed in these cases, he profits as a result. Therefore, addressing the agency problem means providing incentives for the agent to behave in accordance with the principal's wishes.

The law of contract does not presently provide adequate incentives for a promisor in a negative covenant situation to perform the promise. If compensatory damages are inadequate and specific performance is no

${ }^{87}$ Blake (n 1) 287. $\quad{ }^{88}$ Thel and Siegelman (n 14) 25.

${ }^{89}$ JE Stiglitz, 'Principal and Agent (ii)' in SN Durlauf and LE Blume (eds), The New Palgrave Dictionary of Economics (2nd edn Palgrave Macmillan, London 2008). 
longer available, the promisor has discretion to breach which he should not have. In a situation like Blake, compensatory damages were inadequate. Blake, the 'notorious traitor', published an unauthorized autobiography in breach of his contract, and without the consent of the British government. His actions had not caused a pecuniary loss to the Crown which could be compensated. Nor could the government restrain George Blake from publishing his book; it had already occurred. In addition, the purpose of the contract was not to make a profit, but to protect the government, and the case involved a relationship of trust and confidence. It is appropriate to have incentives to promote performance on the part of promisors in these kinds of contracts. This conclusion is not without precedent. As Robert Cooter and Bradley J Freedman have argued, the agency problem in breach of fiduciary duty has been dealt with by the availability of profit stripping remedies. ${ }^{90}$

The chapter first explains the role of substitutability in breach of negative covenant cases, and then turns to explore the agency problem in more detail.

\section{Substitutability in breach of negative covenant cases}

Although the primary focus of the negative covenant cases is the agency problem, substitutability is still a relevant factor, particularly where disgorgement is awarded as a surrogate for expectation damages. ${ }^{91}$ Plaintiffs will wish to claim gain-based damages in circumstances where the defendant has benefited in a measurable way and has caused a loss which is speculative or hard to quantify. ${ }^{92}$ The kinds of case in which it is typically difficult to measure the losses of the plaintiff are intellectual property infringement cases, in which it is very difficult to ascertain the plaintiff's losses resulting from the infringement, but the sales of the defendant are clear and quantifiable. Two of the post-Blake cases could be said to fit within this scenario: World Wide Fund for Nature $v$ World Wrestling Federation Entertainment $I n c^{93}$ and Experience Hendrix $L L C v$

90 R Cooter and BJ Freedman, 'The Fiduciary Relationship: Its Economic Character and Legal Consequences' (1991) 66 NYULR 1045, 1047.

91 Eisenberg (n 4) 587-8.

92 D Laycock, 'The Scope and Significance of Restitution' (1989) 67 Tex L Rev 1277, 1287.

93 [2001] EWHC Ch 482 (' $\left.W W F^{\prime}\right)$. Although note the dismissive comments of Jacobs J at [62]: "The fact that [the contract] relates to the use of initials and so is a bit "trademarkish" or "IPish" does not mean the common law should provide [disgorgement damages].' 
PPX Enterprises Inc. ${ }^{94}$ Each case involved a settlement contract in which the defendant had breached an agreement not to use certain intellectual property belonging to the plaintiff (the initials 'WWF' in the first case and the recordings of Jimi Hendrix in the second case). In both cases, it was very hard for the court to ascertain the losses caused by the breach, but the profits were clear.

... The nature of the breach of negative covenant cases is such that we will never know what would have happened had the defendant not breached the covenant, and therefore, the defendant has not only put specific relief out of the plaintiff's reach, he has also made it very difficult for her to calculate her losses. The defendant has deprived the plaintiff of performance, the plaintiff cannot obtain a substitute performance, and nor can she be adequately compensated for her loss.

However, although the principle of substitutability thus plays a role in determining disgorgement damages for breach of a negative covenant, it will be seen that agency problems and policy considerations also play a part in the breach of negative covenant cases. In order to see how the agency problem operates, it is first necessary to look at breach of fiduciary duty.

\section{The agency problem in breach of fiduciary duty cases}

It is clear that profit-stripping remedies are available where a fiduciary has profited from a breach of fiduciary duty. ${ }^{95}$ The reason for this stems from the nature of the fiduciary obligation itself. Fiduciaries are required to act in the interests of the beneficiary, and not in a self-interested fashion. Fiduciary obligations have two principal aspects:

(1) The fiduciary must not place him or herself in a position of conflict between his or her own interests and his or her duty to the beneficiary, nor may the fiduciary place himself or herself in a conflict between his or her duties to two or more beneficiaries.

(2) The fiduciary must not make an unauthorized profit from his or her fiduciary position. ${ }^{96}$

${ }_{94}$ [2003] EWCA Civ 323 ('Experience Hendrix').

${ }^{95}$ M Conaglen, 'The Nature and Function of Fiduciary Loyalty' (2005) 121 LQR 452, 463.

96 Chan v Zacharia (1984) 154 CLR 178, 199 (Deane J). 
The deterrent philosophy of fiduciary law is said to demand that a fiduciary be prevented from profiting at the expense of a beneficiary ${ }^{97}$ Even bona fide fiduciaries must disgorge any unauthorized gains obtained in the discharge of their fiduciary role. ${ }^{98}$

Fiduciary duties may be imposed outside the 'presumptive circle', even in the context of a contractual relationship which is ordinarily selfinterested. As Mason J noted in Hospital Products Ltd v United States Surgical Corporation, ${ }^{99}$ a person may come under a fiduciary relationship in a range of circumstances.

The critical feature of these relationships is that the fiduciary undertakes or agrees to act for or on behalf of or in the interests of another person in the exercise of a power or discretion which will affect the interests of that other person in a legal or practical sense. The relationship between the parties is therefore one which gives the fiduciary a special opportunity to exercise the power or discretion to the detriment of that other person who is accordingly vulnerable to abuse by the fiduciary of his position ... It is partly because the fiduciary's exercise of the power or discretion can adversely affect the interests of the person to whom the duty is owed and because the latter is at the mercy of the former that the fiduciary comes under a duty to exercise his power or discretion in the interests of the person to whom it is owed. ${ }^{100}$

Alternatively, it is said that the fiduciary has the exercise of a power or discretion to which the beneficiary is vulnerable. ${ }^{101}$

${ }^{97}$ See Edelman (n 4) 83-5, 212; M McInnes, 'Account of Profits for Common Law Wrongs' in Degeling and Edelman (n 20) 405, 428; Conaglen (n 95) 463; J Edelman, 'GainBased Damages and Compensation' in A Burrows and Lord Rodger of Earlsferry (eds), Mapping the Law: Essays in Memory of Peter Birks(Oxford University Press, Oxford 2006) 141, 147-50; A Duggan, 'Solicitors' Conflict of Interest and the Wider Fiduciary Question' (2007) 45 CBLJ 414, 421-2; PD Finn, 'The Fiduciary Principle' in TG Youdan (ed), Equity, Fiduciaries and Trusts (Carswell, Toronto 1989) 26. Cf L Smith, 'The Motive, Not the Deed' in J Getzler (ed), Rationalizing Property, Equity and Trusts: Essays in Honour of Edward Burn (LexisNexis Butterworths, London 2003) 53.

98 See Keech $v$ Sandford (1726) Sel Cas King 61, 25 ER 223; Boardman v Phipps [1967] 2 AC 46; Regal (Hastings) Ltd v Gulliver [1967] 2 AC 134; Canadian Aero Service v O'Malley (1973) 40 DLR (3d) 371.

99 (1984) 156 CLR 41 ('Hospital Products'). ${ }^{100}$ Ibid 96-7 (Mason J).

101 There are also parallels with Dawson J's 'vulnerability' test from Hospital Products at ibid 142: 'There is, however, the notion underlying all the cases of fiduciary obligation that inherent in the nature of the relationship itself is a position of disadvantage or vulnerability on the part of one of the parties which causes him to place reliance upon the other and requires the protection of equity acting upon the conscience of that other.' Dawson J's test was preferred by the Supreme Court of Canada in LAC Minerals Ltd $v$ International Corona Resources Ltd [1989] 2 SCR 574, 61 DLR (4th) 14. 
Commentators have searched for a unifying principle of fiduciary relationships, but the cases are notoriously difficult to rationalize. Justice Easterbrook and Daniel Fischel have suggested that the reason why it is difficult to discover a unifying principle of fiduciary relationships is because scholars are mistakenly looking for something unique or special about fiduciary relationships. ${ }^{102}$ They argue that fiduciary relationwhips are just one extreme of a spectrum of contractual and consensual relations. ${ }^{103}$ Fiduciary relationships tend to arise when a transaction is complex, and one party wishes to confer discretion on another, but it is too difficult specifically to enumerate each and every undertaking. ${ }^{104}$ Fiduciary relationships are a species of voluntary undertaking where certain terms are implied into the agreement between the parties. ${ }^{105}$

Another hallmark of the fiduciary relationship is that it is very difficult to monitor whether or not the fiduciary is undertaking his or her duties. ${ }^{106}$ Cooter and Freedman argue that because of the agency problem, fiduciaries are difficult to supervise, and therefore gain-stripping remedies are the law's way of controlling and penalizing fiduciaries for any breach of duty. ${ }^{107}$ Disgorgement strips the fiduciary of his or her gain from misappropriation, so that from the fiduciary's perspective, it is as if the wrong had not been committed. ${ }^{108}$ Any incentive to profit is removed. Disgorgement damages deter fiduciaries from misappropriation.

The case which had particular resonance for the majority of the House of Lords in the Blake case was Snepp $v$ United States ${ }^{109}$ a fiduciary duty case which otherwise bore an uncanny resemblance to Blake. Snepp, a former employee of the Central Intelligence Agency (CIA) was liable to disgorge profits made by releasing an unauthorized book about the United States', in particular the CIA's, activities in Vietnam. The US Supreme Court was prepared to find that Snepp owed concurrent contractual and fiduciary obligations to the CIA and awarded a constructive trust in favour of the CIA over the profits from Snepp's book.

102 FH Easterbrook and DR Fischel, 'Contract and Fiduciary Duty' (1993) 26 I Law and Economics $425,438$.

${ }^{103}$ Ibid 425-38. ${ }^{104}$ Ibid 426-7; Thel and Siegelman (n 14) 24.

105 See especially, J Edelman, 'When Do Fiduciary Duties Arise?' (2010) 126 LQR 302; J Edelman, 'Four Fiduciary Puzzles', ch 13 in this collection; A Duggan, 'Contracts, Fiduciaries and the Primacy of the Deal', ch 12 in this collection.

106 Cooter and Freedman (n 90) 1048-9; Easterbrook and Fischel (n 102) 427.

107 Cooter and Freedman (n 90) 1046-7.

108 Ibid 1051. 109444 US 507 (1980) ('Snepp'). 
The similarities between Blake and Snepp highlight the overlap between the fiduciary duty cases and the breach of negative covenant cases generally, because the rationale behind the two is so similar. It is trite to say that the label fiduciary has often been misused in order to achieve a just result. ${ }^{110}$ In particular, some cases seem to have been called 'fiduciary' merely to obtain the disgorgement remedies which fiduciary law offers.

- Some of the cases which have been placed into the 'fiduciary basket' could be better analysed as cases where disgorgement damages were awarded for breach of a negative covenant. ${ }^{111}$ Clearly profit-stripping remedies are seen as an appropriate method of deterring breaches of fiduciary duty; it is suggested that the same should be the case with some negative covenant cases, particularly those where the promisor has a duty which involves the public interest or trust on the part of the promisee.

\section{The agency problem in breach of negative covenant cases}

As discussed, there is an overlap between cases involving injunctions to restrain a breach of negative covenant and cases involving concurrent breach of contract and fiduciary duty. ${ }^{112}$ One of the suggestions of the Court of Appeal in Blake was that disgorgement damages should be awarded where the defendant had done 'the very thing which he agreed not to do. ${ }^{113}$ This was rejected by Lord Nicholls. ${ }^{114} \mathrm{~A}$ better approach would be to qualify Lord Woolf's analysis by specifying that in negative covenant cases, the defendant agreed to do something for the benefit of the plaintiff and, if the defendant had kept his obligations, he would have foregone the profit he in fact obtained. Having done the very thing he had agreed not to do, and having made a profit thereby, the defendant should be obliged to disgorge that profit.

Easterbrook and Fischel argue that negative covenants are often included in contracts where one party seeks to govern the future conduct of the other, but cannot specify exactly which obligations will arise in advance without costly and inconvenient negotiation. ${ }^{115}$ They regard

110 P Birks, 'Restitutionary Damages for Breach of Contract: Snepp and the Fusion of Law and Equity' [1987] LCMLQ 421.

111 Some of the concurrent breach of fiduciary duty cases cited with approval in Blake could perhaps be better categorized as breach of negative covenant cases: see eg, ReidNewfoundland Cov Anglo-American Telegraph CoLtd [1912] AC 555; ReadingvAttorneyGeneral [1951] AC507 (cf speech of Lord Denning in Reading v The King [1948] 2 KB 268, 276-7).

112 Smith (n 81) 127. "133 Attorney-General v Blake [1998] Ch 439, 458.

114 Blake (n 1) 286. $\quad{ }^{115}$ Easterbrook and Fischel (n 102) 444-5. 
the negative covenant in the Snepp case as setting in train a process for making decisions in the future as to what Snepp could and could not write. Snepp should have tried to negotiate a second contract to ascertain exactly which parts of his manuscript could be published:

The first contract established the employment relation and the submission requirement. The second contract would establish the terms of publication. Just as restitution plus an additional penalty induces the would-be thief to enter into market transactions instead, the profits remedy induces the parties to contract explicitly. It is a contract-inducing, not a contractfrustrating, approach. ${ }^{115}$

On this analysis, the disgorgement remedy removes the incentive for the promisor to breach, and instead gives the promisor incentive to negotiate with the promisee.

A further reason why disgorgement damages tend to be awarded for breaches of fiduciary duties or breach of negative covenant is because these contracts often involve a conferral of trust on the promisor by the promisee (to a greater or lesser degree), and therefore courts are willing to say for public policy reasons that these contracts should not be breached. ${ }^{117}$ In circumstances where a contract is one which imports a special degree of trust or reliance, disgorgement damages will often be the best or only way to effectuate the contract and to give the promisor efficient incentives to perform. ${ }^{118}$ It is also worth noting that punitive damages tend to be awarded for particular kinds of breach of contract where there is a special sense of trust, in which one party is open to being 'used' by the other. ${ }^{119}$ These contracts include contracts of insurance and the like.

Unfortunately, after Blake, courts have seemed unsure of how to treat cases involving breach of negative covenant. In each of $W W F^{120}$ and Experience Hendrix $x^{121}$ it is suggested that the contracts concerned typified the agency problem, and the plaintiffs had reposed trust in the defendants. Accordingly, full disgorgement damages should have been payable. The settlement contracts in each case were essentially non-substitutable, and the loss suffered by the plaintiffs was uncertain and speculative. Further, in each case, the plaintiff had trusted the defendant to refrain from committing the very breach which occurred, and neither contract was designed to serve a profit-making purpose. ${ }^{122}$ Indeed, in both cases

116 Ibid 444. $\quad 17$ Eisenberg (n 4) 588-92. ${ }_{118}$ Ibid 592.

${ }_{119}$ Chapman and Trebilcock (n 9) 765-7. ${ }_{120}$ WWF (n 93).

121 Experience Hendrix (n 94) (Mance LJ, Hooper J and Peter Gibson LJ).

122 See following discussion on profit-making purpose. 
the contract involved was a settlement, and thus the plaintiffs would have been forgiven for thinking that their troubles were over once the settlement was entered into. It was difficult for the plaintiffs in each case to supervise the performance of the obligation. It is in precisely these sorts of circumstances that disgorgement remedies should be available, if a profit has been made. ${ }^{123}$

There are other public policy reasons for imposing disgorgement damages. Melvin Eisenberg suggests disgorgement damages are awarded in cases where bargains were designed to serve interests other than profitmaking. ${ }^{124} \mathrm{He}$ argues that:

[C]ourts should protect the disgorgement interest in the case of bargain contracts that are not designed for profit-making purposes, so as to give the promisor in such contracts efficient incentive to perform, and effectuate contracts of this type..$^{125}$

Blakeand Snepp involved national security interests, but this is not the only kind of case which raises public policy issues in the context of contracts not entered into for profit. In British Motor Trade Association v Gilbert, ${ }^{126}$ the defendant sought to sell his car in breach of a contractual term preventing the unauthorized sale of second-hand cars. An injunction restraining the breach had been obtained, but the defendant sold the car anyway. The policy of the post-World War II legislation which gave rise to the restraint in the contract was to regulate and limit the sale of cars to prevent an inflationary black market. The defendant was ordered to pay an account of profits made by him as a result of the breach of the injunction. ${ }^{127}$ Eisenberg argues that the contract in Gilbert created an 'externality', which meant that the contract should benefit the public rather than the contracting parties. In these kinds of cases, disgorgement damages will be the best or only way to effectuate the contract and to give the promisor incentives to perform because the public may not have standing to sue. ${ }^{128}$

The policy concerns in Snepp, Blake and Gilbert can be united under a single head of bargains designed to serve the public and interests other than profit-making. On this analysis, it is far more likely that a court will order disgorgement damages for breach of negative covenant or fiduciary

${ }^{123}$ See K Barnett, 'Deterrence and Disgorging Profits for Breach of Contract' [2009] RLR 79, 89-90.

${ }^{124}$ Eisenberg (n 4) 588. ${ }^{125}$ Ibid 591. ${ }^{126}$ [195I] 2 All ER 64I ('Gilbert').

127 Ibid 645. ${ }^{128}$ Eisenberg (n 4) 592. 
duty if the purpose of the bargain was to serve the public, or to serve interests other than profit-making.

\section{Conclusion}

This chapter asserts that disgorgement damages cases may be divided a. according to whether they are 'second sale' cases or 'agency problem' cases. As has been noted by other scholars, substitutability is an important key to establishing liability for disgorgement damages for breach of contract, but it must be nuanced according to the context.

In the second sale cases, if the plaintiff can obtain a substitute performance, damages will be adequate. And if a court can still order specific relief, it should do so in preference to ordering disgorgement damages. Disgorgement damages will only be ordered if the performance was nonsubstitutable, specific relief is no longer available and the defendant has made a profit. This still leaves room for the concept of 'efficient breach' in a second sale case in certain circumstances, but only if the subject matter of the contract is substitutable.

In the agency problem cases, the critical point is that there is a relationship of trust between the plaintiff and the defendant. Typically, the defendant has made a promise that he will not do something which would prejudice the plaintiff, which promise cannot be monitored by the plaintiff, but the defendant goes ahead and breaches anyway. In those circumstances, whether one classes the promise as fiduciary or not, there are public policy reasons for deterring such conduct. Disgorgement damages should be available in order to give efficacy to these promises. This is particularly the case where contracts are not-for-profit contracts, where compensatory damages may not adequately protect the plaintiff's interest in performance. Disgorgement damages provide an incentive for the defendant to perform or to negotiate a release rather than to leave a plaintiff 'high and dry'. 


\section{University Library}

\section{- M M I E E R VA A gateway to Melbourne's research publications}

Minerva Access is the Institutional Repository of The University of Melbourne

Author/s:

Barnett, K

Title:

Substitutability and disgorgement damages in contract

Date:

2010-01-01

Citation:

Barnett, K. (2010). Substitutability and disgorgement damages in contract. Bant, E (Ed.). Harding, M (Ed.). Exploring Private Law, (1), pp.377-401. Cambridge University Press.

Persistent Link:

http://hdl.handle.net/11343/30212 